\title{
LIFETIME GLASS REINFORCED PLASTIC PIPES BY MEASURING THE STIFFNESS
}

\author{
Ana Diana Ancas a, *, M. Profire a, I. L. Cirstolovean b, M. Hornet ${ }^{\text {b }}$, G. Cojocaru ${ }^{\text {c }}$ \\ $a^{*}$ Technical University "Ghe. Asachi" of Iasi, Faculty of Civil Engineering and Building Servicies, Department Building Sevicies, \\ D. Mangeron 67 str., 700050, Iasi, Romania, e-mail: ancas05@yahoo.com \\ ${ }^{\mathrm{b}}$ University "Transilvania" of Brasov, Faculty of Civil Engineering, Turnului 5 str., 500152, Brasov, Romania \\ ${ }^{c}$ Amianti Pipe System (APS), Bucharest, Romania
}

Received: 20.02.2018 / Accepted: 28.02.2018 / Revised: 03.04.2018 / Available online: 31.05.2018

DOI: 10.2478/jaes-2018-0001

KEY WORDS: GRP pipe, lifetime, stiffness, types of land.

\begin{abstract}
:
The lifetime of glass reinforced plastic pipes is 50 years. Extensive use of this type of pipe in its various applications, led to investigate their behavior in land that anthropogenic or natural causes, shows the different values of $\mathrm{pH}$ to neutral. The paper presents experimental results conducted on three samples of a PN SN10000 DN150 PN10 pipe buried in three different types of terrain: neutral, acidic, basic. They were subjected to axial load, measuring the force applied deformation force function. On the basis of the calculation formulas determined rigidity of the pipeline, the deformation speed of $50 \mathrm{~mm} / \mathrm{min}$. This concludes the type of land affects the rigidity of the pipe so its length of life decreases to that provided by suppliers in order to be taken compensatory measures in this regard such as choosing a higher class of pressure and stiffness pipeline than those arising discounted. This will allow for long-term value (50 years) in the mechanical characteristics sufficient for safe operation.
\end{abstract}

\section{INTRODUCTION}

GRP pipes have a semi-elastic behavior (cooperates with the land, and surrenders some of its load) and anisotropic (different mechanical properties in the axial direction or roll).

Of all the materials used, water and sewage has reduced the carbon footprint (greenhouse gas relative amount of gases emitted in their production).

Compared to the other materials used in wastewater treatment GRP pipes have the following characteristics:

-corrosion resistance;

-low weight;

-high standard lengths;

-hydraulic characteristics superior;

-high life span;

-low expansion coefficient;

-greater flexibility.

Design lifetime of glass reinforced plastic (GRP) pipes is 50 years. Experimental data and preliminary studies show that some types of GRP pipes (such as Flowtite Grey Pipe) can have a good safety in service for more than 100 years (David-West et.al. 2008). Basically, this estimate is based on the slope of the regression stiffness, which should ensure the end of designed life value of its $60 \%$ of the original assumed (eg, a pipe SN 10000 will have to be over 50 years a stiffness of at least 6000
$\mathrm{N} / \mathrm{m}^{2}$ ), where $\mathrm{SN}$ is the specific rigidity of the pipe (Shukry et.al., 2013, Isama, 2013). All these considerations are based on the premise pipe fitting according to the manufacturer's instructions (Aveston and Sillwood, 1982, Tanaka et.al., 1997, Mahmoud and Tantawi, 2003) and an operating under the conditions specified by the standard that is, lying in the ground with a soil $\mathrm{pH}$ of the solution as close to neutral.

In the case of acidic or basic land, the life of the pipe may suffer a reduction which is assumed to be proportional to the deviation from neutral $\mathrm{pH}$. On the basis of experimental data obtained in the evaluation of the rigidity of the pipe lay in the ground three types: neutral, acidic, basic is desired lifetime of the pipe.

\section{METHODS}

\subsection{Testing stiffness}

To determine the stiffness was used universal testing machine INSPEKT SXL 600XL (Photo 1), manufactured by Hegevald und Peschke in Dresden, Germany.

This machine was designed specifically for measurements on pipes of GRP, is totally adapted to meet standards for this material.

\footnotetext{
* Corresponding author: Ana Diana ANCAS, e-mail: ancas05@yahoo.com
} 
Testing is done on specimens with a length of about $300 \mathrm{~mm}$, the diameters of DN150 and DN4200.The rate of deflection can vary between 0.002 and $450 \mathrm{~mm} / \mathrm{min}$. The standard test which was conducted to ASTM D 2412 (Standard Test Method for determining the characteristics of GRP pipe to the external load modeled by parallel plates).

The procedure consists of measuring the deformation of a short section of pipe subjected to compression between two rigid plates, with the rate of deformation constant. The force monitoring deformation and strain specific, it refers to the values that crack, delamination or tearing.

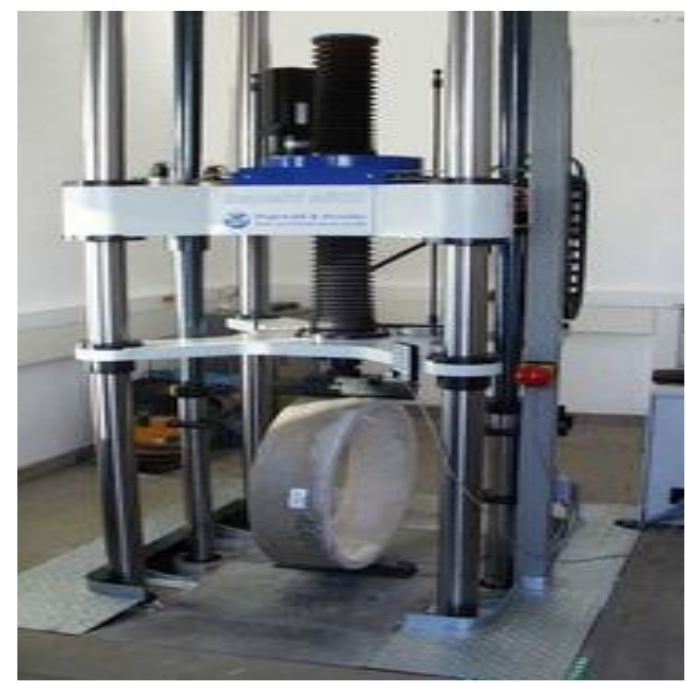

Photo 1. INSPECKT SXL 600XL Equipment

\subsection{Measurement of change stiffness pipe}

In assessing the stiffness was chosen reference system, namely a pipe sample GRP DN150 SN10000 PN 10 was buried in a neutral of the Bacau city, Romania, field that has been installed prior to this type of line and which did not generate problems operation.

Also to assess changing stiffness depending on the nature of the land, another sample was buried everything in Bacau, Romania but in a land acid, area expolatarii oil Petrom and a third sample in a field alkaline area Solonţ, Bacau, Romania .

After 24 months, samples were unearthed and analysed.

Verification of stiffness was done on each test piece of each pipe consisting of a pipe section with a length of about $297 \mathrm{~mm}$ (Photo 2), according to the procedure described in ISO7685.

These sections were subjected to an axial load, deflection and measuring the force applied continuously. The deflection rate was $50 \mathrm{~mm} / \mathrm{min}$.

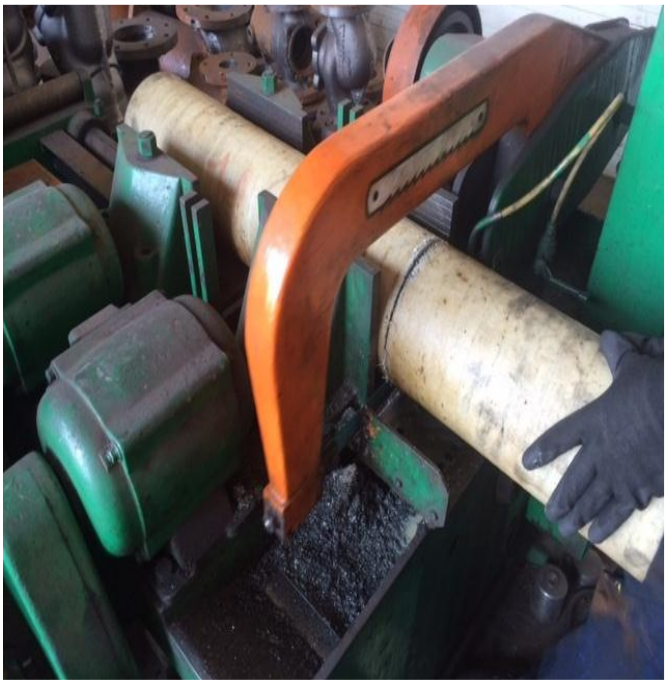

Photo 2. Cutting samples

SN specific stiffness, is a physical characteristic of the pipe, in $\mathrm{N} / \mathrm{m}^{2}$. The extent transverse deformation resistance per meter length, below the external load, and is defined by the equation:

$$
S N=\frac{E \cdot I}{d_{m}^{3}}
$$

where,

-E is the modulus apparent elasticity, which can be determined from the test results of the transversal strength, expressed in $\mathrm{N} / \mathrm{m}^{2}$,

$-\mathbf{d}_{\mathbf{m}}$ is the average diameter of the pipe, in $\mathrm{m}$,

-I is the moment of inertia in the longitudinal direction per unit length, expressed in $\mathrm{m}^{4} / \mathrm{m}$ (Norwood, 1984, Mateescu et.al., 2000).

$$
I=\frac{e^{3}}{12}
$$

where,

$-\mathbf{e}$ is the thickness of the pipe wall.

The average diameter of a circle $\mathbf{~ d m}(\mathrm{m})$ corresponding to the diameter of the circular section of the pipe wall means and is given by the equation:

$$
\begin{aligned}
& d_{m}=d_{e}-e \\
& d_{m}=d_{i}+e
\end{aligned}
$$

where,

-de, di and e are the outer diameter, inner, wall thickness, respectively.

Additionally, the standard requires visual inspection of the pipeline to achieve the two-stage deformation ( 9 and $15 \% \mathrm{DN})$. 9\% threshold need not be present any cracks or delamination, 
and at $15 \%$ cracks are superficial and do not penetrate into the depth of the wall and may not appear delamination (Renoud, 2009, Rafee, 2013).

\section{RESULTS AND DISCUSSIONS}

The results of the strength test as in Table 1 are obtained for a variation of the axial deformation force according to Figure 1.

Table 1. Rigidity test results

\begin{tabular}{|c|c|c|c|c|c|c|c|c|c|}
\hline 产 & 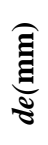 & $\widehat{\mathrm{\Xi}}$ & ఏ్త & 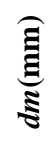 & $\begin{array}{l}\text { छ } \\
\text { छે }\end{array}$ & $\sum_{\mathbf{L}}$ & 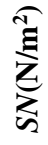 & 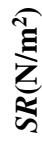 & $\sum_{\text {Z }}^{\overparen{J}}$ \\
\hline ت & กֶ. & $\stackrel{テ}{+}$ & $\begin{array}{l}0 \\
\hat{a}\end{array}$ & $\stackrel{n}{\mathbb{f}}$ & $\stackrel{\vartheta}{\dot{r}}$ & $\begin{array}{l}0 \\
\dot{D}\end{array}$ & $\begin{array}{l}n \\
\stackrel{n}{n} \\
\stackrel{n}{N}\end{array}$ & $\stackrel{\infty}{\stackrel{0}{0}}$ & $\begin{array}{l}\overrightarrow{6} \\
6 \\
=\end{array}$ \\
\hline 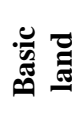 & ชి & F & 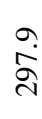 & $\begin{array}{l}+ \\
\dot{J}\end{array}$ & $\stackrel{q}{\dot{r}}$ & 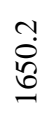 & $\begin{array}{l}\stackrel{\vartheta}{\tilde{r}} \\
\vec{N}\end{array}$ & $\stackrel{5}{0}$ & \begin{tabular}{l}
$n$ \\
$\infty$ \\
\multirow{+}{*}{} \\
0
\end{tabular} \\
\hline 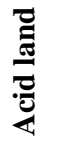 & ชุ & F & $\frac{\mathfrak{s}}{\mathfrak{d}}$ & $\stackrel{n}{\mathbb{b}}$ & ๆे & $\stackrel{\infty}{\infty}$ & 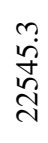 & $\stackrel{\infty}{\stackrel{\infty}{0}}$ & $\begin{array}{l}n \\
\stackrel{2}{ } \\
\end{array}$ \\
\hline
\end{tabular}

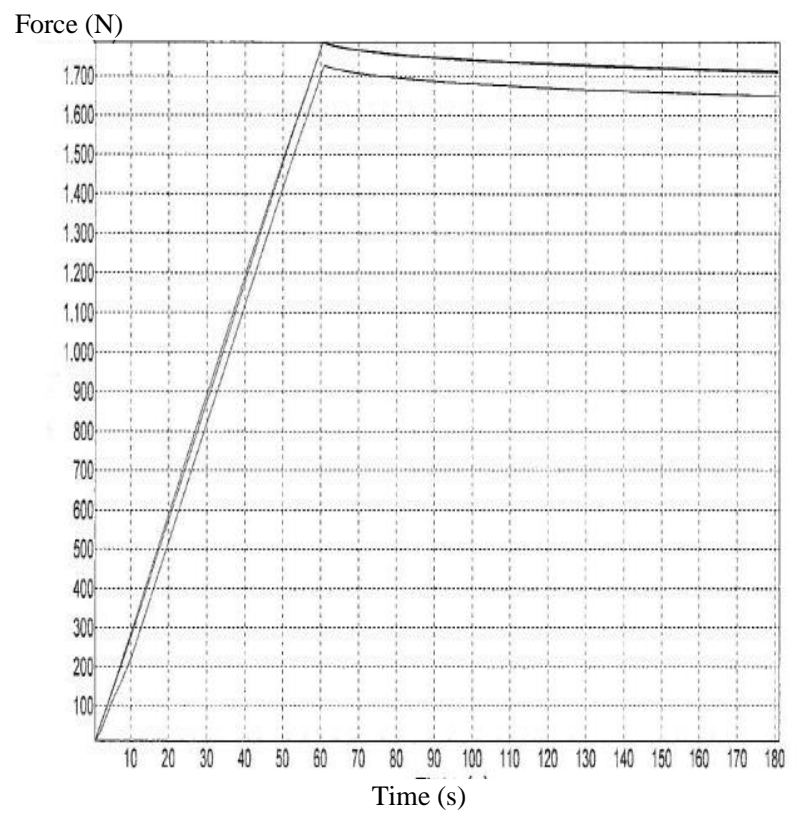

Figure 1. The variation of axial deformation force

Related stiffness variation and sizes depending on the nature of the land is shown in Figure 2.
It notes the time of collapse of the three samples identical to $\mathrm{T}=60$ seconds. At a constant deformation speed of $50 \mathrm{~mm} / \mathrm{min}$ results in a short-term strain at break of $33 \%$, greater than the $20 \%$ required by the standard, so a value coverings. Comparing the design values of stiffness $\mathrm{SN}$ and considering the safety factor FS (1.8 standards regarding GRP pipe production), will give the following values (Table 2):
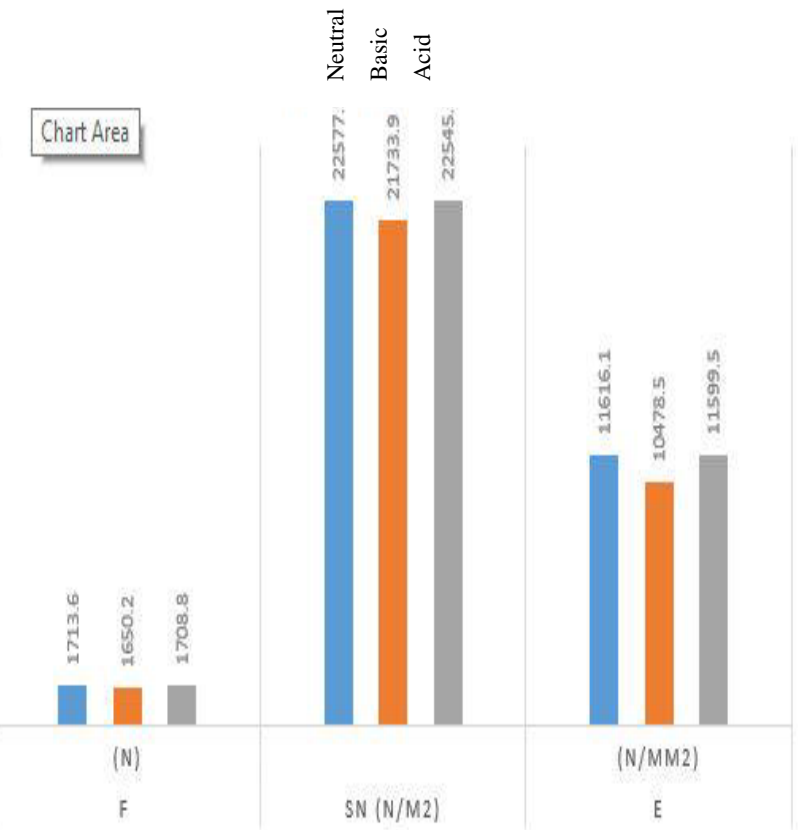

Figure 2. Variation stiffness and related measurements measured according to land

Table 2. Revised values of stiffness

\begin{tabular}{|c|c|c|c|c|}
\hline Sample & $\begin{array}{c}\mathbf{S N}_{\text {calculate. }} \\
\left(\mathbf{N} / \mathbf{m}^{2}\right)\end{array}$ & $\boldsymbol{F S}$ & $\begin{array}{c}\mathbf{S N}_{\text {revised }} \\
\left(\mathbf{N} / \mathbf{m}^{2}\right)\end{array}$ & $\begin{array}{c}\text { Clasa } \\
\mathbf{S N}\end{array}$ \\
\hline Neutral land & 22577.5 & 1.8 & 12543.1 & 10000 \\
\hline Basic land & 21733.9 & 1.8 & 12074.4 & 10000 \\
\hline Acid land & 22545.3 & 1.8 & 12525.2 & 10000 \\
\hline
\end{tabular}

The higher values than class rigidity, so after two years does not appear on a downgrading stiffness.

\subsection{Calculation of the damage to the pipe stiffness}

According (Amaro et. al., 2013, Adams and Cawlwy, 1998) to quantify damage to the composite pipe by the application SN stiffness in Table 1 (the amount of force which passes the elastic behavior of the sample in the plastic) will result in:

$$
D r=1-\frac{S N}{S N_{0}}
$$

where, $S N_{0}$ is the specific sample stiffness in neutral land. 
Thus, if the index field impairment acid $D r$ is:

$$
D r=1-\frac{22545.3}{22577.5}=0.001
$$

and if basic land:

$$
D r=1-\frac{21733.9}{22577.5}=0.04
$$

\subsection{Calculation of correction Pearson stiffness}

By entering in Table 1 and the $\mathrm{pH}$ values of the three fields and calling the Pearson correlation coefficients (Ancas et. al., 2017) will result in the following Pearson Correlation Matrix (Table 3):

Table 3. PH- stiffness coefficients of correlation

\begin{tabular}{|c|c|c|c|c|c|}
\hline Variables & $\boldsymbol{p H}$ & $\boldsymbol{F}$ & $\boldsymbol{S N}$ & $\boldsymbol{S R}$ & $\boldsymbol{E}$ \\
\hline $\boldsymbol{p H}$ & $\mathbf{1}$ & -0.839 & -0.857 & -0.874 & -0.867 \\
\hline $\boldsymbol{F}$ & -0.839 & $\mathbf{1}$ & $\mathbf{0 . 9 9 9}$ & $\mathbf{0 . 9 9 8}$ & $\mathbf{0 . 9 9 8}$ \\
\hline $\boldsymbol{S N}$ & -0.857 & $\mathbf{0 . 9 9 9}$ & $\mathbf{1}$ & $\mathbf{0 . 9 9 9}$ & $\mathbf{1 . 0 0 0}$ \\
\hline $\boldsymbol{S R}$ & -0.874 & $\mathbf{0 . 9 9 8}$ & $\mathbf{0 . 9 9 9}$ & $\mathbf{1}$ & $\mathbf{1 . 0 0 0}$ \\
\hline $\boldsymbol{E}$ & -0.867 & $\mathbf{0 . 9 9 8}$ & $\mathbf{1 . 0 0 0}$ & $\mathbf{1 . 0 0 0}$ & $\mathbf{1}$ \\
\hline
\end{tabular}

Increasing the $\mathrm{pH}$ to a reduction in the rigidity of the measured value (value of the correlation coefficient -0.857 , respectively).

Entering the values in Table 2 and $\mathrm{Na}^{+}$ion concentration and calling specific to the three lands Pearson correlation coefficients will result in the following Pearson correlation matrix (Table 4):

Table 4. The correlation coefficients $\mathrm{Na}^{+}(\mathrm{mg} / 100 \mathrm{~g}$.sol - stiffness and sizes associated

\begin{tabular}{|c|c|c|c|c|c|}
\hline Variables & $N a^{+}$ & $F$ & $S N$ & $S R$ & $E$ \\
\hline$N a^{+}$ & 1 & -0.999 & -1.000 & -1.000 & -1.000 \\
\hline$F$ & -0.999 & 1 & 0.999 & 0.998 & 0.998 \\
\hline$S N$ & -1.000 & 0.999 & 1 & 0.999 & 1.000 \\
\hline$S R$ & -1.000 & 0.998 & 0.999 & 1 & 1.000 \\
\hline$E$ & -1.000 & 0.998 & 1.000 & 1.000 & 1 \\
\hline
\end{tabular}

The high values, but of all the negative correlation coefficients of the stiffness matrix demonstrates the decrease with increasing concentration of alkali ions in the laying ground.

\subsection{Estimating the lifetime of the pipe}

Based on the above data and from the measured stiffness pipe laid in neutral as reference value by assuming a linear regression of these characteristics in the long term can simulate the stiffness after 50 years (Figure 2), comparing it the one required by the standard $(60 \%$ of the original according to AWWA C950)

Presuming the development of long-term rigidity (50 years) of the sample at neutral to comply with the provisions of the standards limit (60\% value). Samples of the pitch acid or base will evolve towards keeping the rate of degradation of neutral assumed sample value as the base (Tarakcioglu et.al. 2005, Faria and Guedes, 2010).

Stiffness $\left(\mathrm{KN} / \mathrm{m}^{2}\right)$

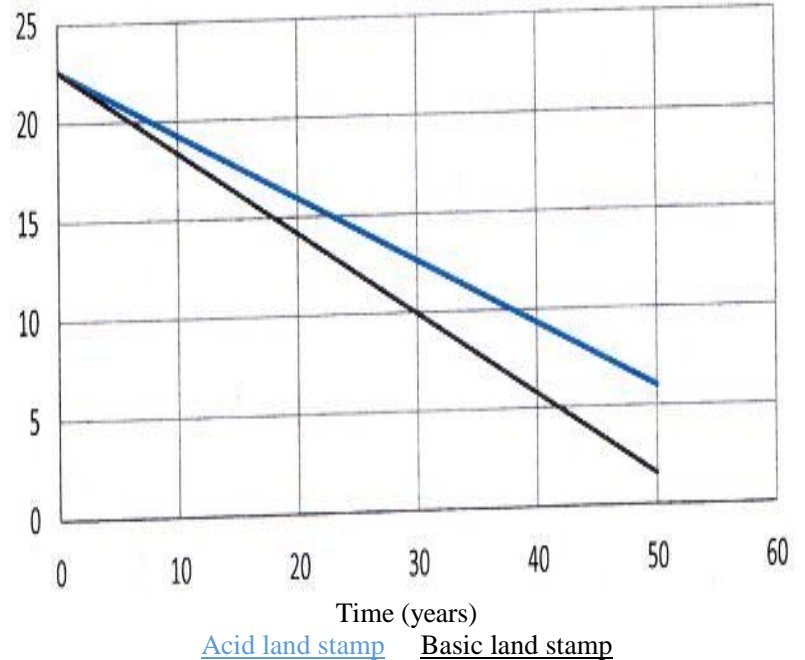

Figure 3. Estimated linear stiffness term variation

It is noted evolution of the pitch acid sample, with a 50 year $12.04 \mathrm{kN} / \mathrm{m}^{2}$, higher than the one imposed by the standard. In contrast, the sample of the pitch base expediency degrades greater than that permitted by the standard, to a value of $1.54 \mathrm{kN} / \mathrm{m}^{2}$ to 50 years.

To sample the field posed acid (basically similar to the neutral), the function of the linear impairment:

$$
f(x)=a x+b
$$

will form:

$$
f(x)=-331.54 x+22577
$$

For the sample basic laid in the ground (similar to the practically neutral) position of the linear impairment (6) takes the form:

$$
f(x)=-421.5 x+22577
$$


and hence limit value of SN6000 touches to 39.33 years.

The conclusion is that a change of $\mathrm{pH}$ from 7 to 8.18 generates a decrease in the lifetime of 50 to 40 years. Route acid sample undergoes alterations field of life, in terms of rigidity.

\section{CONCLUSIONS}

The influence of $\mathrm{pH}$ on the mechanical characteristics of GRP pipes is evident. Degradation is directly proportional to the exposure to soil with non-neutral reaction, but mostly proportional to the difference between the actual value of soil $\mathrm{pH}$ of the solution and neutral $\mathrm{pH}$.

All these considerations are based on the premise installation of pipes according to the manufacturer's instructions and the operation specified by the standard conditions, that is, laying in the ground with a soil $\mathrm{pH}$ of the solution as close to neutral. In the case of acidic or basic land, the life of the pipe may suffer a reduction which is assumed to be proportional to the deviation from neutral $\mathrm{pH}$.

$\mathrm{Na}^{+}$content increased stiffness influences, in particular pipes. Pearson correlation coefficients show negative acceleration of the degradation of unitary pipes in direct proportion to the amount of $\mathrm{Na}$ ions.

To compensate for these degradations proposed solutions would be:

- The choice of a higher class of pressure and stiffness than those arising from the computation of the hydraulic or static (for example, using a pipe PN10 PN6 SN10000 instead of one generated by sizing calculations SN5000 / verification). The gravity-flow pipes critical situation, the choice of a class of high rigidity is sufficient. This will allow for long-term value (50 years) in the mechanical characteristics sufficient for safe operation, despite the steep curve of regression of these characteristics over time.

- The gravity-flow pipes critical situation, the choice of a class of high rigidity is sufficient.

These things help enable long-term value (50 years) in the mechanical characteristics sufficient for safe operation, despite the steep curve of regression of these characteristics over time.

For further research we propose evaluating deformation under chemical stress.

\section{References}

Amaro, A.M.; Reis, P.N.B.; Neto, M.A.; Louro, C., 2013. Effects of alkaline and acid solutions on epoxy/glass composites. Polymer degradation and stability, 98(4), pp.853862, https://doi.org/10.1016/j.polymdegradstab.2012.12.029.
Adams, R.D., Cawley, P.D., 1998. A review of defect types and non-destructives testing techniques for composites and bonded joints. Non Destructive Techniques Int., 219(4), pp.208-22, https://doi.org/10.1016/0308-9126(88)90333-1.

Ancas, A.D., Profire, M., Cojocaru, G., 2017. Experimental Evaluation a Tensile Strength of PAFSIN Pipes in Different Types of land. Journal of Applied Sciences, 7(20), pp. 11-16, http://doi.org/10.1515/jaes-2017-0007.

Aveston, J., Sillwood, J.M., 1982. Long-term strenght of glassreinforced plastics in dilute sulphuric acid. Journal of Material Science, 17(12), pp. 3491-3498.

AWWA C950-13. Fiberglass Pressure Pipe - American Water Works Association.

David-West, O.S., Nash, D.H.; Banks, W.M., 2008. An experimental study of damage accumulation in balanced CFRP laminates due to repeated impact. Composites Structures, 83(3), pp.247-258, https://doi.org/10.1016/j.compstruct.2007.04.015.

Faria, H., Guedes, R.M., 2010. Long term behaviour of GRP pipes.Reducing the prediction test duration. Polymer Testing, 29, pp.337-345.

Isama, L., 2013. Effects of crude oil spillage on soil physicochemical properties in Ugborodo community. International Journal of Modern Engineering Research, 3(6), 3336-3342.

ISO 7685. Plastics piping systems -- Glass-reinforced thermosetting plastics (GRP) pipes -- Determination of initial specific ring stiffness

Mahmoud, M.K., Tantawi, M.K., 2003. Effects of strong acids on mechanical properties of GRP pipes at normal and high temperatures. Polym Plast Technol Eng, 42, pp.677-88, https://doi.org/10.1081/PPT-120023102

Mateescu, T., Profire, M., Pop, A., Ciascai I., 2000. Conducte din mase plastice pentru sisteme de utilități urbane. Ed. Revox, Bistrița.

Norwood, L.S., Hogg, P. J., 1984. GRP in contact with acid environments: a case study. Composites Science Technology, 2(1), pp.1-22, https://doi.org/10.1016/0263-8223(84)90040-0.

Rafiee, R., 2013: Experimental and theoretical investigations on the failure of GRP pipes. Composites PartB, 45, pp.257267,https://doi.org/10.1016/j.compositesb.2012.04.2009

Renoud, W., Moubarac, R., 2009. In search of the optimum pipe material for seawater services. Fiberglass Structural Engineering, Washington.

Shukry, W.M., Al-Hawas, G.H.S., Al-Moaikal, R.M.S., ElBendary, M.A., 2013. Effect of petroleum crude oil on mineral nutrient elements, soil properties and bacterial biomass. British journal of environment and climate change, 3(1), pp.103-118.

Tanaka, H., Kuraoka, K., Yamanaka, H., Yazawa, T., 1997. Development and disappearance of microporous structure in acid treated E-glass fiber. Journal of Non Crystalline Solids, 
215(2-3), pp.262-70, https://doi.org/10.1016/S0022-3093 (97) 00103-8.

Tarakcioglu, N., Gemi, N.L., A.Yapici, A., 2005. Fatigue failure behaviour of GRP pipes under internal presure. Comp Sc and Technology, 65(3-4), pp.703-708. 